\title{
Interests Analysis on Compulsory License
}

\author{
Meirong Guo \\ KoGuan Law School, Shanghai Jiaotong University, Shanghai, China \\ Email: guomeirong@sjtu.edu.cn
}

Received 23 May 2016; accepted 29 August 2016; published 2 September 2016

Copyright (C) 2016 by author and Scientific Research Publishing Inc.

This work is licensed under the Creative Commons Attribution International License (CC BY).

http://creativecommons.org/licenses/by/4.0/

(c) (i) Open Access

\begin{abstract}
In this paper I turn to different conceptions of interest. There are several theories in the field of political philosophy about what interest is and therefore several conceptions of interest exist. Three pairs of interest are clarified: interest as welfare and interest as resource, reflective interest and volitional interest, public interest and private interest. Especially, interests in compulsory licenses are also described, which are including compulsory licenses and the conceptions of interest, diversity of interests and interest in pharmaceutical industry. By these analyses, we can see interests in compulsory licenses in general and in pharmaceutical industry.
\end{abstract}

\section{Keywords}

Interest, Compulsory License, Political Philosophy

\section{Introduction}

There are several theories in the field of political philosophy about what interest is and therefore several conceptions of interest exist. In this paper, three pairs of interest are clarified: interest as welfare and interest as resource, reflective interest and volitional interest, public interest and private interest. Especially, interests in compulsory licenses are also described, which are including compulsory licenses and the conceptions of interest, diversity of interests and interest in pharmaceutical industry. By these analyses, we can see interests in compulsory licenses in general and in pharmaceutical industry.

\section{Different Conceptions of Interest}

\subsection{Interest as Welfare and Interest as Resource}

It seems useful to offer a pair of conceptions of interest in order to explore this concept. There are three pairs of conceptions of interest; they are interest as welfare and interest as resource, reflective interest and volitional interest, and the public interest and private interest. I will elaborate these in the follows. First, there are two views 
of interest: interest as welfare and interest as resources. It is necessary to make clear what welfare is before defining what the interest as welfare is. Ronald Dworkin divides several theories about what welfare is into two main groups.

The first group is success theories of welfare, which suppose that a person's welfare is a matter of his success in fulfilling his preferences, goals, ambitious, and so on. Since people have different sorts of preferences, different versions of interest as welfare are in principle available. The second class of theories of welfare is conscious-state theories. Jeremy Bentham and other early utilitarians took welfare to consist in pleasure and the avoidance of pain. But most contemporary utilitarians and other partisans of the conscious-state conception of welfare believe that pleasure and pain are much too narrow to represent the full range of conscious states that should be included (Dworkin, 2000). From the theories about what welfare is, we can see that taking interest as a person's welfare is a matter of his success in fulfilling his preferences, goals, and ambitious; therefore, the equality of achieving success is a conception of interest as welfare.

The second group argues taking income and assets and some economic benefits or profits as a material view of interest. Moreover, freedom and opportunity are on behalf of social view of interest. The two views of interest are taken as a conception of interest as resource. John Rawls identifies primary goods as the "things that every rational man is presumed to want” (Rawls, 1971). Primary goods are subdivided in two categories: natural primary goods including intelligence, imagination, and health; social primary goods including rights (for example, civil rights and political rights), liberties, income and wealth, and the social bases of self-respect. However, no matter what the primary goods is, interest as resource is always thought to link to non-welfarism. Individuals are responsible for their decisions and actions, not, however, for circumstances beyond their control (such as race, sex, and skin-color), but also intelligence and social position, which are excluded as distributive criteria. Equal opportunity is insufficient because it does not compensate for unequal innate gifts.

This argument makes me think that one of the aims of setting compulsory licenses is to protect the public interest. (Here the health of patients are taken as the public interest.) Suppose that without pharmaceutical compulsory licenses, more infants born in poor families still have no money to buy medicine in developing countries. They need treatment while being innate AIDs patients, whereas the medicine is too expensive to pay. From the standpoint of interest as resource, after implementing the compulsory licenses in pharmaceutical field, the medicine becomes cheaper and thus the poor AIDs patients can get it. In a broader sense, they truly achieve the equality of treatment opportunity.

\subsection{Reflective Interest and Volitional Interest}

Second, I distinguish reflective interest from volitional interest. "Volitional interest" is a term coined by Ronald Dworkin, while reflective interest is different from what he calls critical interest. If one holds or achieves what in fact one wants, we can say, his volitional interest is promoted. One's reflective interest is advanced when one maintains or accomplishes what one would deliberatively want if one were well informed and made a choice with no fraud, threat, or mental disorder, irrespective of whatever is actually desired (Usami, 2008). At first, I will explain the idea of volitional interest by differentiating volitional interest from critical interest. What makes a life a good or successful one? Philosophers in the utilitarian tradition assume that the success of different lives can be measured and compared in respect of a single elemental carrier of ethical value.

They debate the merits of two competing claims: first, that ethical value consists in an identifiable psychological experience, such as pleasure and pain. Second, that it consists in the phenomenon of having one's desires satisfied. Someone's volitional well-being is improved when he has or achieves what he wants actually. His critical well-being is improved by his having or achieving what it makes his life a better life to have or achieve. For example, because I like Japanese very much, speaking Japanese well is my volitional interest. I do want to speak it well and am disappointed because I can't yet. I can't think that my life would be a worse one if I had never conceived that desire. It is important for me to speak Japanese well because I want to speak well, not vice versa. By contrast, make an example of critical interest. I want to sing well because I do think my life would have been better, but I had never understood the importance of this; it is not my volitional interest, because I just happen to want it. The distinction between volitional and critical well-being is not the distinction between what is sometimes called subjective and objective well-being, however. It is true that a critical interest has an objective dimension that a volitional interest does not. The two kinds of interests and the two modes of well-being are distinct. Nor is critical interest the same as motive. Critical and volitional interests are interconnected in various 
ways. Critical interests often track volitional interests. And volitional interest normally tracks opinion about critical interest.

Reflective interest is different from critical interest. Drug abuse is reflective disinterest to everyone, because every healthy people has ability to know drugs are detrimental to human health, even though drug addicts do what them. One's reflective interest is advanced when one maintains or accomplishes what one would deliberatively want if one were made a choice with no fraud is actually desired. Whatever their race or sex, every citizen has the equal right to vote according to the Constitution. The equal right to vote is reflective interest. Every citizen has equal right of education, and so on. In some sense, volitional interest is linked to the conception of welfarism. In democratic country, various kinds of volitional interests of citizen are embodied by law through voting in national assembly election.

The distinction between volitional interest and reflective interest helps to grasp Chinese people's interests in the context of environmental problems. Many people look forward to achieving rapid economic development while ignoring the impact on environment, and in some places citizen breathe fresh air has been a dream. Unsustainable development may bring about wealth, and people are richer which satisfies their volitional interest. However, when they know fresh air is closely with their health, and if compulsory licenses can facilitate on renewable energy technology, they could breathe fresh air freely, and energy crisis would relieve in the future. They do benefit to all of the nationals and meet all reflective interests of nationals.

\section{Public Interest}

In the first section, I presented the pair of interest as welfare and interest as resource, and that of volitional interest and reflective interest. In this section, I will focus on the public interest. In fact, the term of "public interest" is not strange to us, because we hear or see it usually by news or broadcast. It is often proclaimed that the task of government is to serve or promote the public interest. Moreover, if asked whether public policy should be in accord with the public interest or with private interests, most people would opt for the former. However, when one is asked how to define the public interest? Many people, including most political scientists, would say that it is not possible to provide a universally accepted or objective definition of the concept, especially in substantive terms. Thus sometimes the public interest is depicted as a myth by which policy, however particularistic, can be rationalized as in the general interest and hence made more publicly acceptable (Anderson, 2011).

Then, let us consider the following questions before seeking what on earth the public interest is, for it can help us. Is public interest the interest of the majority? If so, how do we determine what policy the majority really wants? Is it the interest of consumers, if so, who are a rather large group? Is it what people would want if they "thought clearly and acted rationally"? And so on. Some theorists elaborate the public interest by differentiating two kinds of interest: public interest and private interest, depending on the range of persons enjoying it. The public interest means a gain shared by all or most of members, whereas private interest refers to a benefit that only some members of society receive. Consuming private goods is private interest for the consumer, whereas enjoying public goods does not necessarily fall into the public interest.

The public interest does not mean all the members of society can enjoy it, maybe it means most of the members of society can obtain the public goods. Here the society can refer to the world, a nation, or a province and so on. The question now arises: how to determine what public goods are? Paul Samuelson (1954) notes that some goods, once they are made available to one person, can be consumed by others at no additional marginal cost (Posner \& Weisbach, 2010); this condition is commonly called jointness of supply or nonrivalness in consumption, because your consumption of the goods does not affect mine, as your breathing air would not block my breathing it. In fact when we talk about the public interest, we often mean the public interest of state more accurately. Let us consider the armed forces as the public good because everyone in a society is enjoying it. National defense that protects the country against attacking from abroad, based on the course, it is taken as the public good of the state. In China when the patent invention is revolving the national defense or security, compulsory licenses on it can be admitted.

We can go on argue for what is often called the public-goods theory of the state (Baumol, 1952) (more generally see Hardin, 1997). The public-goods account gives us a clear normative justification of the state in welfarist terms: The state resolves many centrally important and potentially pervasive free rider problems. It does not give us an explanatory account of the origins of the state; although it could arguably contribute to the explanation of the maintenance of a state once it exists. It might do so through support for the state's collective provisions and 
therefore support for the state. Although enjoying public goods does not attribute to the public interest, how to determine what constitutes the public interest is the question now.

Redford (1957) suggests three approaches to this task. One is to look at policy areas in which conflicts among group interests exist, such as energy and transportation. In some instances the direct interests of one group or another may prevail and become accepted as the public interest. There is no reason to assume that private interests and the public interest must always be antithetical. The second approach is to search for widely and continuously shared interests that, because of these characteristics, can be called the public interest. Illustrative are the interests of people in such matters as world peace, better education, clean air, avoidance of severe inflation, and an adequate traffic-control system. Here the public interest appears to be the satisfaction of public needs. The third approach to determining the public interest is to look at the need for organization and procedures to represent and balance interests, to resolve issues, to effect compromise in policy formation, and to carry public policy into effect. There is, in short, a public interest in the fair, orderly, and effective government.

\section{Interests in Compulsory Licenses}

\subsection{Compulsory Licenses and Conceptions of Interest}

Based on the distinctions between different conceptions of interest I presumed in the previous section, the conception of interest as resource and reflective interest support implementing compulsory licenses. Then, we will talk about these two kinds of interests respectively. One of the aims of establishing patent is to promote more inventions by providing potential inventors with economic incentives; carrying out compulsory licenses enables many people to use the necessary commodities. They achieve the opportunities, and have interest as resource. For instance, because of implementing compulsory licenses in pharmaceutical sector, AIDS patients in poor countries can buy their necessary drugs in a cheap price, and thus they achieve interest as resource.

If compulsory licenses are implemented, one's reflective interest will be advanced when he is well informed and made a choice with no fraud. For example, if R \& D (Research \& Development) expenditures are spent in renewable energy technology, more new renewable energy technology will be invented. If compulsory licenses in renewable energy technology will be implemented, therefore, more people can take advantage of these technologies and relieve problems, such as climate change, environmental pollution and so on. Even if volitional interest of inventor will be declined when implementing compulsory license, reflective interest will be increased by means of other R \& D technology.

According to Chinese Patent Law, compulsory licenses can be implemented in the following situations of public interest: important patent related to national defense security, such as the invention of advanced weapon; important patent related to national economy, such as the invention of pollution mitigation; important patent related to public health, such as the invention can effectively prevent or treat some serious illness. From these, we can make a conclusion that public interests in Chinese compulsory licenses mainly refer to the three fields of national defense security, public health and national economy. Here, the public interests are closely to public needs according to the second approach, which is appropriately in accordance with me. Except these, available resources are also widely and continuously shared interests.

\subsection{Diversity of Interests}

In essence, under compulsory license, an individual or company seeking to use a patent can do so without the patent holder's consent and that individual or company pays the patent holder a set fee for the license. If a patentee and a licensee make contract of patent license transfer voluntarily, the patent license will be exclusive license or non-exclusive license. The rights and obligations of the two parties are agreed by themselves; the same as all other contracts. In contrast, in a compulsory license, whether the patentee would like to transfer his licenses to the licensee or not, he has to do so. Because his purpose may be violated, the volitional interest of patentee is reduced without a doubt.

On the other hand, the licensee may obtain the patent license in a cheaper price or other favorable conditions and thus his profit is certainly increased. According to the principle of free contract, only protecting the interests of one party of contract is not permissible. In fact, one of the aims of setting compulsory licenses is safeguarding the public interest. Two-party contract, in most of occasions, is the agreement between individuals and companies. Do their interests belong to the public interest? According to the previous analysis, the interests of the two 
parties should be classified as private interest. However, there is the third party exists; that is consumer, who is consuming the commodities produced by taking advantage of the patent in compulsory licenses. Because there are many consumers, the sum of their interests should be attributed to the public interest.

Take the case of AIDS as an example. Forty million people are infected by the AIDS virus in developing countries, with 26.6 million in the African continent. About 93\% of those infected with the AIDS virus cannot afford to buy the anti-retroviral medication, which they need (Baker, 2004). The Joint Program of the United Nations on AIDS believes that unequal access to medical treatment at acceptable prices is one of the main reasons for the low levels of survival in poor nations. In addition to AIDS, the poor in developing countries are victims of a large number of infectious diseases such as tuberculosis, malaria, respiratory infections and so on diseases, for which there is little or no access to medication. Compulsory licensing reduces prices of medicines (Do Amaral, 2005). For this reason, compulsory licenses lead to undeniable social benefits that can be translated into easier access to medication by significant part of the population. These patients are all consumers. The health of some patients will be restored and the lives of some patients will be saved. It is obvious that the volitional interests of patients will be improved and public interests will be promoted.

\subsection{Interests in Pharmaceutical Industry}

According to previous statements of public interest, the public needs can be attributed to the public interest. Public health is also looked as the needs of public health, which is "the science and art of preventing disease, prolonging life and promoting health through the organized efforts and informed choices of society, organizations, public and private, communities and individuals” (Winslow, 1920). It is concerned with threats to health based on population health analysis. The population in question can be as small as a handful of people or as large as all the inhabitants of several continents, for instance, in the cases of a SARS (Severe Acute Respiratory Syndrome) and AIDS. Under Article 27(1) of the TRIPS Agreement, patents must be available for all fields of technology. This scope of coverage includes the availability of patents for pharmaceutical products.

However, when considering the availability of patents for pharmaceutical products, one must also take into account the right to health. Article 25 of the Universal Declaration of Human Rights, states explicitly that "Everyone has the right to a standard of living adequate for the health and well-being of himself and his family, including food, clothing, housing and medical care...” (United Nations, 1948). The right to health obliges a government to take into account HIV/AIDS in respecting, protecting and fulfilling the right to health. Get the right means to achieve the interest. For consumers, their interests will be met. On the other hand, the rights of the creator are not absolute but conditional when contributing to the common good and welfare of society. Thus for creators, their interests will be limited.

Individual right is always relates to community rights, when rights to health of millions of people are threatened, it is undoubtedly evolved into public health emergency. Every year approximately ten million people die needlessly because they cannot access existing essential medicines and vaccines. The WTO has recognized this humanitarian crisis and, to its credit, has declared that the TRIPS agreement must be interpreted in a way to protect public health and promote development ${ }^{1}$. TRIPS allows for compulsory licenses of patented technology without the authorization of the patent owner in times of "emergency" (TRIPS 31). Such licenses have typically been employed in the past for pharmaceutical products used to fight epidemics such as AIDS, but the scope of compulsory licenses has recently been widened to include long-term health problems such as heart disease and cancer.

Recognizing "the gravity of the public health problems afflicting many developing and least-developed countries, especially those resulting from HIV/AIDS, tuberculosis, malaria and other epidemics"², with the commencement of the "Development Round" of World Trade Organization negotiations, member countries adopted the groundbreaking Declaration in the TRIPS Agreement and Public Health. The Doha Declaration unequivocally holds that patent rights cannot trump the rights of millions of people to health and dignity, or the rights of states to meet the humanitarian needs of their peoples. Significantly, it clarifies that TRIPS "does not and should not prevent members from taking measures to protect public health”3.

\footnotetext{
${ }^{1}$ From goods to a good life/Intellectual property and Global Justice/MADHAVI SUNDER-P186.

${ }^{2}$ World Health Organization, Declaration on the TRIPS Agreement and Public Health, para.1 (2001), (hereinafter Doha Declaration), available at http://www.wto.org/English/thewto_e/mindecl trips_e.htm.

${ }^{3}$ Id. at para. 4.
} 
The Doha Declaration reaffirms that developing countries can exercise flexibilities built into the TRIPS agreement to meet the public health needs of their citizens, in particular highlighting that any member state has a right to grant compulsory license on medicines-essentially reverting that country's patent law to pre-TRIPS days-so as to allow the production and importation of less expensive generic drugs. The declaration assures that each member state has "the freedom to determine the grounds upon which such licenses are granted"-stipulating that this includes but is not limited to cases of national or medical emergency - and there is no exhaustive list as to which diseases can be treated ${ }^{4}$. Furthermore, the Doha Declaration recognized that not all countries were equally positioned to issue compulsory licenses. It also noted that WTO members with insufficient or no manufacturing capacities in the pharmaceutical sector could face difficulties in making effective use of compulsory licensing under the TRIPS Agreement, and recognized that the least developing nations are dependent on other countries, like India, for the supply of cheap generic drugs ${ }^{5}$. In 2007, Thailand approved a compulsory license for the AIDS drug Kaletra after failing in its attempts to receive a price reduction on the drug. The licenses allowed domestic drug makers to copy the patent holder's formula and sell the medicine domestically, saving thousands of lives (Collins-Chase, 2008).

Even those states incapable of domestically manufacturing the licensed products have benefited from compulsory licenses. In 2007, Canada took advantage of the 2003 WTO Decision Implementation of Paragraph 6 of the Doha Declaration on the TRIPS Agreement and Public Health by issuing a compulsory license for the production and export of an AIDS drug to Rwanda (Tsai, 2009). Compulsory licenses have also been granted by Eritrea, Ghana, Guinea, Malaysia, Swaziland, and Zimbabwe for the importation of AIDS medication from abroad (DeRoo, 2011).

The Doha calls for limiting patent holders' rights in drugs to accommodate public health crises and permits compulsory licenses to correct a moral failure. The Doha Declaration recognizes that countries have the "right to grant compulsory licenses", and "the freedom to determine the grounds upon which such licenses are granted"”. In fact, the declaration simply reaffirmed nations' rights already outlined in the TRIPS agreement. Notably, and contrary to popular perception, the TRIPS agreement does not limit states' use of compulsory licenses to any particular diseases, such as HIV/AIDS or malaria. Neither does TRIPS direct that compulsory licenses to meet their public health needs as they themselves determine these needs. The declaration reaffirms "the right of WTO Members to use, to the full, the provisions in the TRIPS Agreement, which provide flexibility for this purpose"

\section{Conclusion}

I talked about the three pairs of interest: interest as welfare and interest as resource; reflective interest and volitional interest; public interest and private interest. Among them, the conceptions of interest as resource, reflective interest and public interest are taken as supports to my research. In the part of interest in compulsory license, we can see that a patentee, a licensee and consumers have different interests, and the interests of other parts will be improved except a patentee in compulsory licenses whether in general or in pharmaceutical industry.

\section{References}

Anderson, J. E. (2011). Public Policymaking: An Introduction (pp. 150-153). Wadsworth Political Science (Part of Cengage Learning).

Baker, B. K. (2004). Arthritic Flexibilities for Accessing Medicines: Analysis of WTO Action Regarding Paragraph 6 of the Doha Declaration on the Trips Agreement and Public Health. Indiana International \& Comparative Law Review, 613, 705.

Baumol, W. J. (1952). Welfare Economics and the Theory of the State. Harvard: Harvard University Press.

Collins-Chase, C. T. (2008). The Case against TRIPS-Plus Protection in Developing Countries Facing AIDS Epidemics. University of Pennsylvania Journal of International Law, 763, 765.

DeRoo, P. (2011). Public Non-Commercial Use Compulsory Licensing for Pharmaceutical Drugs in Government Health

\footnotetext{
${ }^{4}$ Id. at para. 5(b).

${ }^{5}$ Id. at para.6.

${ }^{6}$ Alcorn, K. “Abbott to Withhold New Drugs from Thailand in Retaliation for Kaletra Compulsory License”. AIDS Map News. Accessed March 15, 2013. http://www.aidsmap.com/en/news/00C7641B-57F5-4AB8-8876-9040425D4464.asp.

${ }^{7}$ Doha Declaration, para. 5(b).

${ }^{8}$ Doha Declaration, para. 4.
} 
Care Programs. Michigan Journal of International Law, 32, 347-394.

Do Amaral, A. (2005). Compulsory Licensing and Access to Medicine in Developing Countries. Yale Law School Legal Scholarship Repository.

Dworkin, R. (2000). Sovereign Virtue: the Theory and Practice of Equality (pp. 17-18, 242-245). Harvard: Harvard University Press.

Hardin, R. (1997). Economic Theories of the State. Perspectives on Public Choice: A Handbook (pp. 21-34). Cambridge: Cambridge University Press.

Posner, E. A., \& Weisbach, D. (2010). Climate Change and Future Justice. Princeton: Princeton University Press.

Rawls, J. (1971). A Theory of Justice (pp. 54-79). Harvard: Harvard University Press.

Redford, E. S. (1957). Ideal and Practice in Public Administration. Alabama: University of Alabama Press.

Samuelson, P. (1954). The Pure Theory of Public Expenditure. The Review of Economics and Statistics, 36, 387-389. http://dx.doi.org/10.2307/1925895

Tsai, G. (2009). Canada’s Access to Medicines Regime: Compulsory Licensing Schemes under the WTO Doha Declaration. Virginia Journal of International Law, 50, 1063.

United Nations (1948). Universal Declaration of Human Rights.

Usami, M. (2008). Law as Public Policy: Combining Justice with Interest. In T. Biernat, \& M. Zirk-Sadowski (Eds.), Politics of Law and Legal Policy: Between Modern and Post-Modern Jurisprudence (pp. 292-315). Warsaw: Wolters Kluwer Polska.

Winslow, C. E. A. (1920). The Untilled Fields of Public Health. Science, 51, 23-33. http://dx.doi.org/10.1126/science.51.1306.23

\section{Submit or recommend next manuscript to SCIRP and we will provide best service for you:}

Accepting pre-submission inquiries through Email, Facebook, LinkedIn, Twitter, etc.

A wide selection of journals (inclusive of 9 subjects, more than 200 journals)

Providing 24-hour high-quality service

User-friendly online submission system

Fair and swift peer-review system

Efficient typesetting and proofreading procedure

Display of the result of downloads and visits, as well as the number of cited articles

Maximum dissemination of your research work

Submit your manuscript at: http://papersubmission.scirp.org/ 